\title{
Formation of technological quality of grain of millet depending on features of harvesting
}

\author{
M. Blashchuk, \\ PhD in Agricultural Science \\ Cherkasy DHSS NSC "Institute of Agriculture" \\ S. Poltoretskyi, \\ Doctor in Agricultural Science \\ Uman National University of Horticulture \\ V. Bilonozhko, \\ Doctor in Agricultural Science \\ Cherkasy National University named after Bogdan Khmelnytsky
}

The purpose. To improve technique of growing of high-quality grain of millet in conditions of unreliable moistening of Right-bank Forest-steppe. Methods. Laboratoryanalytical, experimentally-field, statistical. Results. Results are given of 4-years probes concerning influence of time of mowing sowings of millet depending on the extent of full maturity of grain in brushes $(25-30 \%, 45-50,65-70$

and $85-90 \%$ ), duration of resting rolls (direct thrashing, thrashing in 3, 6 and 9 day after mowing), and weather environment at that period upon features of formation of technological qualities of grain of millet. Conclusions. Premature to recommended ( $65-70 \%$ of complete ripeness) term of harvesting, and also detention of that time aggravated technological quality of grain and groats. At the necessity to early use sowings of millet for food and feed purposes it is possible to improve a little such situation by separate thrashing of the yield with the following rest of rolsl during 3-6 days. At late harvesting the optimum is direct thrashing.

Key words: millet, technological quality of grain, time of mowing, time of thrashing, duration of rest of roll.

Introduction. Quality of food has a leading role in human life. Their nutritional value depends on the quality of grain, fruits and vegetables. Even a slight improvement in the quality of agricultural products is an additional amount of protein, starch, sugar, fat, vitamins and minerals. The higher nutritional value of agricultural products, the more fully they provide a human body in nutrients and animals in quality feed [1].

Actual scientific researches and issue analysis that initiated the solution to this problem. In the millet cultivation direct harvesting, as well as the separate threshing have become widespread. Depending on the soil-climatic and variety characteristics, scientists give preference to each of them. Typically, the direct harvesting is most often used for full maturity of $50-60 \%$ of seeds, as well as in cases when the plant height is less than $45 \mathrm{~cm}$ or thin stand and low inclined panicle [2]. Other scientists [3] point out its drawbacks - the direct threshing of not fully ripened seeds can cause a significant deterioration of its sowing and technological qualities. To avoid such a phenomenon, they propose to use a two-phase threshing - at first at low revolutions of the threshing unit only ripe and the most weighty seeds are thawed (up to $60 \%$ of the total weight of the harvest) and the rest is thawed in 5-6 days after drying and is used for food or feed purposes [4, 5]. However, other authors [6, 7] point out that the methods of harvesting do not have a significant influence both on the yield of grain and millet seeds and its quality.

Summarizing the research results in the scientific literature, we came to the conclusion that the study of the effect of mowing and threshing terms on the seed quality and yield properties of millet seed is schematic and singular. Under conditions of unstable moistening of Right Bank Forest-Steppe this issue has not been studied at all. This is the relevance and novelty of the chosen direction of studies. 
The research aim was to improve the technology of growing high quality millet grain by studying the mutual influence of mowing terms, duration of windrow maturation and weather conditions during this period under conditions of unstable moistening of the southern part of Right Bank Forest-Steppe.

Materials and methods. The research was carried out in 2011-2014 in the field crop rotation of Department of Plant Production. Two-factor field experiment assumed the following gradations: Factor $A$ (mowing period depending on the degree of maturity of seeds in the panicle) $-25-30 \%, 45-50,65-70$ (check variant) and $85-90 \%$ of seeds had full ripeness; Factor $B$ (duration of windrow maturation) is the direct harvesting and threshing in three, six (check variant) and nine days after mowing. For sowing the medium-season Zolotyste variety was used. The millet predecessor is winter wheat. Phosphate and potash fertilizers were used before fall plowing and nitrogen fertilizers were used before the first spring cultivation at the rate of $\mathrm{N}_{60} \mathrm{P}_{60} \mathrm{~K}_{60}$. The sowing timing is the second decade of May. There are four repetitions; the placement of variants is consistent. Harvesting is according to the research pattern with further grain weighing and finding out the standard humidity and litter. Mowing height for windrows is $12-15 \mathrm{~cm}$. The yield is controlled by test windrows of $1 \mathrm{~m}^{2}$ in all repetitions.

Records, analyzes and observations were conducted in accordance with generally accepted methods [8-14].

The research area is characterized by unstable moisture. The comprehensive evaluation of conditions of humidity and temperature regime during research years on the hydrothermal coefficient (HTC) by G.T. Selianynov shows that the millet growing period in 2012 was characterized as a medium-dry one (HTC $=0.6)$ and 2011, 2013 and 2014 are excessive (HTC = 2.0) and sufficient (HTC = 1.0-1.5) wet ones, respectively. In this case, as a rule, at the time of full maturation, there is hot weather and only in certain years (2011) a significant amount of rain during this period caused a partial deterioration of crops and hampered harvesting.

Research results. As it is known, peculiarities of agricultural machinery and soil-climatic conditions have a significant influence not only on the formation of the productivity level of field crops but also directly affect indicators of its quality. Thus, our previous studies [15], as well as data of other researchers [16], selection of precursors, fertilizer system, soil cultivation, features of sowing, care and harvesting can affect processes of forming sowing qualities and yield properties of seeds and food quality of cereals.

According to the results of our research, timing and methods of harvesting, duration of windrow biomass maturation, as well as weather conditions, in different ways influenced the technological variability of millet grain and yield of cereals (Table 1).

1. Thousand-kernel weight and millet grain unit depending on the characteristics of harvesting, in 2011-2014.

\begin{tabular}{|c|l|c|c|c|c|}
\hline \multicolumn{2}{|c|}{ Experiment variant } & $\begin{array}{r}\text { Thousand-kernel weight, } \\
g\end{array}$ & \multicolumn{2}{c|}{ Grain unit, g/l } \\
\hline $\begin{array}{c}\text { Degree of maturity of } \\
\text { seeds in the panicle } \\
(\text { Factor } A)\end{array}$ & \multicolumn{1}{|c|}{$\begin{array}{c}\text { Duration of windrow } \\
\text { maturation (Factor B) }\end{array}$} & $\begin{array}{c}\text { Average by } \\
\text { Factor B }\end{array}$ & $\begin{array}{c} \pm \text { to the } \\
\text { check } \\
\text { variant }\end{array}$ & $\begin{array}{c}\text { Average by } \\
\text { Factor B }\end{array}$ & $\begin{array}{c} \pm \text { to the } \\
\text { check } \\
\text { variant }\end{array}$ \\
\hline \multirow{3}{*}{$25-30 \%$} & direct threshing & 8.22 & 0.03 & 744 & -11 \\
\cline { 2 - 6 } & three days & 8.52 & -0.28 & 752 & -19 \\
\cline { 2 - 6 } & six days & 8.55 & -0.31 & 749 & -16 \\
\cline { 2 - 6 } & nine days & 8.43 & -0.19 & 741 & -8 \\
\hline \multirow{3}{*}{$45-50 \%$} & direct threshing & 7.99 & 0.26 & 721 & 12 \\
\cline { 2 - 6 } & three days & 8.29 & -0.05 & 736 & -3 \\
\cline { 2 - 6 } & six days & 8.28 & -0.04 & 729 & 4 \\
\cline { 2 - 6 } & nine days & 8.15 & 0.09 & 726 & 7 \\
\hline $65-70 \%$ (check variant) & direct threshing & 0.23 & 715 & 18 \\
\hline
\end{tabular}




\begin{tabular}{|c|c|c|c|c|c|}
\hline & three days & 8.36 & -0.11 & 759 & -26 \\
\hline & six days (check variant) & 8.24 & - & 733 & - \\
\hline & nine days & 8.05 & 0.19 & 722 & 11 \\
\hline \multirow{4}{*}{$85-90 \%$} & direct threshing & 8.05 & 0.19 & 718 & 15 \\
\hline & three days & 7.79 & 0.45 & 711 & 22 \\
\hline & six days & 7.58 & 0.66 & 695 & 38 \\
\hline & nine days & 7.38 & 0.86 & 682 & 51 \\
\hline \multirow{3}{*}{$H I P_{05}$} & Factor $A$ & \multirow{3}{*}{-} & 0.09 & \multirow{3}{*}{-} & 7 \\
\hline & Factor B & & 0.09 & & 7 \\
\hline & Interaction $A B$ & & 0.18 & & 13 \\
\hline
\end{tabular}

Thus, the results of weight measurements of the collected millet grain showed that the weightiest grain was formed at the top of the panicle. Accordingly, thousand-kernel weight and grain unit in the period of 25$30 \%$ degree of maturity of panicles on average amounted to $8.43 \mathrm{~g}$ and $747 \mathrm{~g} / \mathrm{l}$ which is significantly greater by $0.25-0.73$ and $14-45 \mathrm{~g} / \mathrm{l}$ comparatively with other mowing terms $\left(\mathrm{HIP}_{05(\mathrm{AB})}=0.18 \mathrm{~g} \mathrm{i} 13 \mathrm{~g} / \mathrm{l}\right)$. At the same time, to the period of $65-70 \%$ degree of maturation the positive effect of windrow maturation was also noted due to grain ripening in the middle and lower parts of the panicle. During the first two terms of mowing (2530 and $45-50 \%$ of mature seeds in the panicle), windrow biomass maturation of not less than six days significantly increased thousand-kernel weight by $0.29-0.34 \mathrm{~g}$ due to the outflow of nutrients to grain. Further delay with threshing for other three days caused the falling of the weightiest and mature seeds. Thus, the

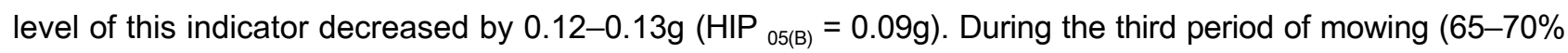
of mature seeds) the minimum duration of this agronomic procedure (three days) was effective. The weight gain was $0.35 \mathrm{~g}$ at a level of $8.36 \mathrm{~g}$. Next delay with harvesting for other three and six days caused a consistent significant decrease by 0.11 and $0.31 \mathrm{~g}$. For the last of the studied periods of mowing $(85-90 \%$ of mature seeds) only the direct threshing was found to be the most suitable $(8.05 \mathrm{~g})$. The separate method of harvesting was accompanied by a significant falling of the weightiest grain, the level of which gradually increased. The variant of combination of the highest degree of maturation and nine-hour windrow maturation was marked by the maximum losses in the experiment. It was possible to get the smallest grain of thousand-kernel weight of 7.38g. Also, similar patterns were observed during the analysis of grain unit - the advantage of early threshing and windrow biomass maturation for three to six days.

Grain collected in the earliest terms (25-30\% of mature seeds) was characterized by the best evenness. Moreover, in case of a separate threshing and lengthening of the duration of maturation from three to six and nine days, due to windrow maturation a significant part of small grain became even $-90.5,91.0,91.7$ and $92.0 \%$, respectively (Table 2 ).

\section{Technological and cereal quality of millet grain depending on the characteristics of harvesting, in} 2011-2014.

\begin{tabular}{|c|c|c|c|c|c|c|c|}
\hline \multicolumn{2}{|c|}{ Experiment variant } & \multirow[b]{2}{*}{$\begin{array}{c}\text { Evenness, } \\
\%\end{array}$} & \multirow[b]{2}{*}{$\begin{array}{c}\text { Hoodness, } \\
\%\end{array}$} & \multirow[b]{2}{*}{$\begin{array}{c}\text { Millet } \\
\text { yield, \% }\end{array}$} & \multirow[b]{2}{*}{$\begin{array}{c}\text { Millet yield, } \\
\text { c/ha }\end{array}$} & \multirow[b]{2}{*}{$\begin{array}{c}\text { Protein } \\
\text { content, } \\
\%\end{array}$} & \multirow[b]{2}{*}{$\begin{array}{c}\text { Fat } \\
\text { content, \% }\end{array}$} \\
\hline $\begin{array}{l}\text { Degree of maturity } \\
\text { of seeds in the } \\
\text { panicle (Factor } A \text { ) }\end{array}$ & $\begin{array}{c}\text { Duration of windron } \\
\text { maturation } \\
(\text { Factor } B)\end{array}$ & & & & & & \\
\hline $25-30 \%$ & direct threst & 90.5 & 18.2 & 70.5 & 11.2 & 11.4 & 2.41 \\
\hline
\end{tabular}




\begin{tabular}{|c|c|c|c|c|c|c|c|}
\hline & three days & 91.0 & 17.9 & 71.0 & 23.6 & 12.3 & 2.45 \\
\hline & six days & 91.5 & 17.5 & 73.0 & 26.5 & 12.5 & 2.37 \\
\hline & nine days & 93.0 & 17.3 & 74.5 & 24.3 & 11.8 & 2.39 \\
\hline \multirow{4}{*}{$45-50 \%$} & direct threshing & 88.0 & 17.8 & 78.5 & 15.8 & 11.5 & 2.64 \\
\hline & three days & 89.5 & 17.5 & 79.0 & 28.2 & 12.0 & 2.79 \\
\hline & six days & 90.0 & 17.4 & 80.0 & 30.2 & 12.1 & 2.77 \\
\hline & nine days & 91.0 & 16.9 & 81.0 & 28.1 & 11.2 & 3.01 \\
\hline \multirow{4}{*}{$\begin{array}{c}65-70 \% \text { (check } \\
\text { variant) }\end{array}$} & direct threshing & 87.5 & 17.1 & 80.5 & 25.7 & 11.9 & 3.16 \\
\hline & three days & 91.0 & 16.8 & 81.0 & 32.0 & 12.6 & 3.17 \\
\hline & $\begin{array}{l}\text { six days (check } \\
\text { variant) }\end{array}$ & 91.7 & 16.5 & 82.0 & 32.5 & 12.4 & 3.16 \\
\hline & nine days & 92.0 & 16.4 & 82.0 & 29.9 & 11.7 & 3.19 \\
\hline \multirow{4}{*}{$85-90 \%$} & direct threshing & 83.0 & 16.9 & 76.0 & 29.4 & 11.7 & 3.31 \\
\hline & three days & 83.5 & 16.5 & 76.5 & 28.5 & 11.5 & 3.42 \\
\hline & six days & 82.5 & 16.0 & 78.0 & 26.6 & 10.9 & 3.39 \\
\hline & nine days & 82.3 & 16.5 & 75.0 & 20.5 & 10.6 & 3.40 \\
\hline $\bar{x}$ & & 88.6 & 17.1 & 77.4 & 25.8 & 11.8 & 2.94 \\
\hline$S$ & & 3.7 & 0.6 & 3.8 & 5.8 & 0.6 & 0.39 \\
\hline$s^{\bar{x}}$ & & 0.9 & 0.2 & 0.9 & 1.4 & 0.1 & 0.10 \\
\hline$V, \%$ & & 4 & 4 & 5 & 22 & 5 & 13 \\
\hline
\end{tabular}

Similar patterns were determined for the next two periods of mowing at a degree of mature seeds of 4550 and $65-70 \%$ in the panicle. Only the longest delay in mowing the windrow biomass maturation did not have a positive effect, but on the contrary, there was a tendency to reduce the grain evenness. It is obvious that for this period millet grain has acquired its final size, completeness and ripeness.

The increase in weight and grain evenness with increasing degree of seed maturity in the panicle and duration of windrow biomass maturation contributed to the reduction of grain hoodness and, consequently, increased the cereal yield. Thus, on average, over the years of research, grain collected in the earliest terms (25-30\% of mature seeds in the panicle) $-17.7 \%$ was characterized by the largest degree of hoodness.

The consistent use of variants of separate threshing improved the technological quality of millet grain, reducing the coating from 18.2 to $17.3 \%$. In this respect, the most suitable was the use of recommended $(65-70 \%)$ and late-lasting (85-90\%) terms of separate harvesting with the duration of windrow maturation of at least three days. So, the grain hoodness collected in these areas was the smallest (within the limits of $16.0-16.8 \%)$. In this case, the obtained experimental data were characterized by high level of evenness $(\mathrm{V}=4 \%)$.

Millet grain was characterized by the maximum yield of cereals harvested in the recommended time (65$70 \%$ of mature seeds in the panicle) by the separate threshing with the duration of windrow maturation of at least 6 days $-82.0 \%$. Reducing the maturation time and direct threshing for this harvesting period reduced this figure to a level of $80.5-81.0 \%$. The high yield of cereals was also achieved by premature mowing period (45-50\% of mature seeds in the panicle) but the duration of windrow biomass maturation should also be from three to six days $(80.0-81.0 \%)$. Very early harvesting term was the least expedient in cultivating millet for food purposes (25-30\% of ripe seeds in the panicle) - the percentage yield of cereals was low and did not reach the level of $75 \%$, while for other harvesting terms the percentage yield of cereals was average (85-90\% of ripe seeds in the panicle), higher than average $(45-50 \%)$ and high $(65-70 \%$ of ripe seeds in the panicle). 
Accordingly, the weight output of cereals also changed. With high variability of obtained data $(V=22 \%)$, the maximum efficiency of growing millet for food purposes was provided by a separate method of harvesting when the degree of its ripeness in the panicle reached $65-70 \%$ and the duration of windrow maturation was within the range of three to six days $-32.0-32.5 \mathrm{c} / \mathrm{ha}$. Transfer in time of duration of both methods of threshing forward (45-50\%) and delay (85-90\%) caused a significant decrease in the level of this indicator (by 1.7-8.4 c/ha). In this respect, the least acceptable was the combination of both very early harvesting period $(25-30 \%$ of ripe grains in the panicle) with a direct threshing and the latest period $(85-90 \%)$ with the longest windrow maturation. Thus, losses were the largest and accordingly amounted to 20.8 and $11.4 \mathrm{c} / \mathrm{ha}$.

The analysis of the protein content indicates that the studied mowing periods and the timing of windrow biomass maturation affected its content in millet grain. Thus, with the transfer in time of harvesting periods from very early ones $(25-30 \%$ of ripe grain in the panicle) to the recommended ones $(65-70 \%$, check variant), the protein content in millet grain tended to increase - from 11.4 to $11.9 \%$ (a direct threshing). A further delay with the grain harvest $(85-90 \%$ of ripe grain in the panicle) was accompanied by a slight decrease (by $0.2 \%$ ) of the level of this indicator. Depending on the duration of windrow maturation, a positive effect of this agricultural method was noted (an increase in the indicator amounted to 2-8\%) but only within three to six days. A further delay with a threshing for other three days caused a decrease in the protein content by $6-8 \%$, while in the late harvesting period (85-90\%) such agricultural method was the least appropriate compared to the direct threshing - such decrease gradually increased from 2 to $10 \%$.

Somewhat differently, the studied agricultural methods influenced the fat concentration in millet grain. So, with the transfer of harvesting terms from very early periods (25-30\% of ripe grain in the panicle) to late ones (85-90\%) and extension of the maturation period the fat content gradually increased - from 2.41 to $3.38 \%$, respectively. In this respect, the direct threshing or the minimum period of windrow maturation in the separate harvesting were the most effective. A further delay with the threshing for other three to six days negatively affected the fat concentration in millet grain.

Consequently, very early (25-30\% and $45-50 \%)$ harvesting period, as well as its delay to the period of $85-90 \%$ of windrow maturation worsen technological qualities of grain and cereals. If the use of cereal crops for food and feed purposes is necessary at early harvesting times, this situation can be improved by using separate crop threshing with windrow maturation for three to six days. In case of the situation with late harvesting terms, this will be facilitated by the direct threshing.

\section{Conclusions}

The weather conditions for research years as well as the use of different terms of mowing and features of threshing cause technological and cereal variety quality of the harvest:

- $\quad$ Grain formed in the upper part of the panicle is the most weighed. When mowing after 25$30 \%$ degree of maturation it is characterized by high thousand-kernel weight and grain unit. Windrow biomass maturation for at least six days substantially increased the level of these indicators. In case of late harvesting $85-90 \%$ of ripeness) the separate threshing causes a significant falling of the most weighed grain;

- Grain harvested in the earliest terms (25-30\% of ripeness) was characterized by the best evenness with the separate harvesting and extension of the maturation duration from three to six and nine days. Due to the windrow maturation, a significant part of small grain became even. However, after late harvesting of $85-90 \%$ ripeness this agricultural method caused only the loss of the weightiest grain;

The increase in weight and grain evenness with increasing degree of seed maturity in the panicle and duration of windrow biomass maturation contributed to the reduction of grain hoodness and, consequently, increased the cereal yield. In this respect, the most suitable was the use of recommended (65-70\%) and late-lasting (85-90\%) terms of separate harvesting with the duration of windrow maturation of at least three days;

With the transfer in time of harvesting periods from very early ones (25-30\% of ripeness) to the recommended ones (65-70\%), the protein content in millet grain tended to increase. A further 
delay with the grain harvest (85-90\% of ripeness) was accompanied by the decrease of the level of this indicator. Depending on the duration of windrow maturation, there is a positive effect only within three to six days;

- With the extension of duration of the maturation period from very early mowing periods to late ones the fat content gradually increases. In this respect, the direct threshing or the minimum period of windrow maturation are the most effective.

- Very early (25-30\% and $45-50 \%$ of ripeness) harvesting period, as well as its delay to the period of $85-90 \%$ of windrow maturation worsen technological qualities of grain and cereals. If the use of cereal crops for food and feed purposes is necessary at early harvesting times, this situation can be improved by using separate crop threshing with windrow maturation for three to six days. In case of the situation with late harvesting terms, this will be facilitated by the direct threshing.

\section{Bibliography}

1. Byelyenixina, A. V., Kostromitin, V. M. (2012). Millet production: results and prospects, distribution and properties. Kyiv. Vol. 19. P. 37-38.

2. Dulov M. I. Volkova A. V., Makushin A. N. (2013). Productivity and quality of millet grain in the Volga region. Samara. $242 \mathrm{p}$.

3. Korenev G. V. (1975). Harvesting qualities of millet seeds harvested in different phases of ripeness. Voronezh. T. 71. P. 49-53.

4. Andrianova L. O. (2012). Methods of caring for crops and harvesting millet in the Middle Urals. Permian. $20 \mathrm{p}$.

5. Agidi, Gbabo1, Ibrahim Mohammed, Gana, Matthew Suberu, Amoto. (2013). Design, fabrication and testing of a millet thresher. Net Journal of Agricultural Science. Vol. 1(4), pp. 100-106.

6. Efanov A. I. (2000). Influence of various methods of pea, buckwheat and millet harvesting on the yield of grain, sowing qualities and yielding properties of seeds in the conditions of the southwestern part of the Central Chernozem Region. Belgorod. $26 \mathrm{p}$.

7. Silas T.A.R., Kajuna (2001). Millet: Post-harvest Operations. Sokone University of Agriculture (SUA), pp. 2-49.

8. Eschenko V. O. et all. (2014). Fundamentals of scientific research in agronomy. Vinnitsa. $332 \mathrm{p}$.

9. The method of state variety testing of agricultural crops. Methods of determining the quality indices of crop production. Whip 7. Kiev, 2000. 144 p.

10. Grain and legume crops and oilseeds. Method for determining the mass of 1000 grains or 1000 seeds. GOST 10842-89. Moscow: Publishing of Standards, 1994. 3 p.

11. Grain. Methods for determining the nature. GOST 10840-64. Moscow: Publishing of Standards, 1986. 4 p.

12. Grain. Methods for determining film frequency. GOST 10843-76. Moscow: Publishing of Standards, 1977. 3 p.

13. DSTU 5026: 2008 Millet. Specifications. Kyiv: Derzhspozhyvstandart of Ukraine, 2010. 14 p.

14. DSTU 4790: 2007. Crouped cultures (buckwheat, millet). Growing technology. General requirements. Kind. Officer Kyiv: Derzhspozhyvstandart of Ukraine, 2009. III. 10 p.

15. Poltoreczkyj S. P., Poltoreczka N. M. (2015). Productivity and quality of the seeds of millet depending on the characteristics of harvesting. Uman. Vol. 87. Part 1: Agronomy. P. 21-29.

16. Kudelko V. N. (2012). Optimization of the methods of cultivation of millet seed (Panicum miliaceum L.) in the conditions of the central part of Belarus. Zhodino. $21 \mathrm{p}$. 